УДК 330.341:316.42]:327.5«713»(1):338.48

JEL Classification: Q01, R11, Z32

ЗЕЛЕНКО О. О. ${ }^{1}$

\title{
ЕКОНОМІЧНО-СОЦІАЛЬНІ ПЕРЕДУМОВИ РОЗВИТКУ ПОСТКОНФЛІКТНОЇ ТЕРИТОРІЇ ЗАСОБАМИ ТУРИЗМУ
}

DOI: $10.32620 /$ cher.2019.4.01

Постановка проблеми: Світова історія містить багато сумних фактів, пов'язаних із політичними конфліктами, які з часом перетворюються на відкрите збройне протистоянні в межах окремих регіонів різних держав. Реінтеграція таких територій у соціально-економічну систему країни може залишитися нездійсненним завданням, тому визначення перспективності розвитку регіону за допомогою провідних галузе економіки, зокрема туризму, є актуальної проблемою. Мета дослідження: аналіз наявного міжнародного досвіду, визначення економіко-соціальних передумов розвитку постконфліктних територій засобами туризму на прикладі сходу України. Предмет дослідження: теоретико-прикладні аспекти застосування інструментів туристичної індустрії для розвитку постконфліктних територій. Методи, використані в дослідженні: системний підхід, структурно-логічний і статистичний аналіз, синтез, узагальнення. Гіпотеза дослідження: передбачає використання підходу, за яким розвиток території засобами туризму розглядається як альтернативна стратегія відновлення соціально-економічного добробуту для мешканців регіону. Виклад основного матеріалу: огляд попередніх досліджень і сучасних історично-зафіксованих фактів вирішення проблем постконфліктних територій дозволив виділити чотири негативних та чотири позитивних передумови, наявність яких обгрунтовує доцільність використання інструментів туристичної галузі для розвитку таких проблемних регіонів. Оригінальність та практична значимість дослідження: результати дослідження, проведеного за даними Луганської і Донецької області, доводять, що туризм не стане провідною галуззю економіки саме для цих регіонів, але його внутрішньо-регіональний розвиток буде каталізатором для відновлення інших галузей економіки. Висновки та перспективи подальших досліджень: враховуючи наявний скептицизм щодо можливостей розвитку туризму на території Донбасу, наступні дослідження будуть присвячені обгрунтованою доцільності розвитку окремих видів туризму саме в цьому регіоні нашої держави.

\section{Ключові слова:}

постконфліктна територія, регіональний туризм, інструменти, розвиток, передумови, економічні і соціальні проблеми.

\section{ECONOMIC AND SOCIAL PREREQUISITES FOR THE DEVELOPMENT OF POST-CONFLICT TERRITORY BY TOURISM MEANS}

Formulation of the problem. World history contains many sad facts related to political conflicts, which over time turn into open armed confrontation within individual regions of different countries. Reintegration of such territories into the socio-economic system of the country may remain an impossible task, so determining the prospects for the development of the region with the help of leading sectors of the economy, in particular tourism, is an urgent problem. The aim of the research: analysis of existing international experience, determination of economic and social prerequisites for the development of post-conflict territories by tourism means on the example of eastern Ukraine. The subject of the research: theoretical and applied aspects of using tourism industry tools for the development of post-conflict territories. The methods of the research: systematic approach, structural-logical and statistical analysis, synthesis, generalization. The hypothesis of the research: involves the use of an approach whereby tourism development is considered as an alternative strategy for restoring socio-economic well-being for the region's inhabitants. The statement of basic materials: review of previous research and current historical facts about solving the problems of postconflict territories revealed four negative and four positive prerequisites, the existence of which substanti-

1 Зеленко Олена Олександрівна, д-р екон. наук, професор кафедри «Міжнародна економіка і туризм», Східноукраїнський національний університет імені Володимира Даля, м. Сєвєродонецьк, Україна.

Zelenko Olena, Doctor of Economic Science, Professor of International Economics and Tourism Department, Volodymyr Dahl East Ukrainian National University, Severodonetsk, Ukraine.

ORCID ID: 0000-0003-4880-246X

e-mail: zelenko.olena@gmail.com 
ates the expediency of using tourism industry tools for the development of such problem regions. The originality and practical significance of the research: the results of this study, conducted according to the data of Lugansk and Donetsk region, prove that tourism will not become a leading sector of economy for these regions, but its intra-regional development will be a catalyst for recovery of other economy branches. Conclusions and prospects for further research: given the existing skepticism about tourism development opportunities in the Donbas, the following studies will focus on the reasonable feasibility of developing certain tourism types in this region of our country.

Key words: lems.

post-conflict territory, regional tourism, tools, development, prerequisites, economic and social prob-

\section{ЭКОНОМИКО-СОЦИАЛЬНЫЕ ПРЕДПОСЫЛКИ РАЗВИТИЯ ПОСТКОНФЛИКТНОЙ ТЕРРИТОРИИ СРЕДСТВАМИ ТУРИЗМА}

Постановка проблемы. Мировая история содержит много печальных фактов, связанных с политическими конфликтами, которые со временем превращаются в открытое вооруженное противостоянии в пределах отдельных регионов разных стран. Реинтеграция таких территорий в социальноэкономическую систему страны может остаться невыполнимой задачей, поэтому определение перспективности развития региона с помощью ведущих отраслей экономики, в частности туризма, является актуальной проблемой Цель исследования: анализ имеющегося международного опыта, определение экономико-социальных предпосылок развития постконфликтных территорий средствами туризма на примере востока Украины. Предмет исследования: теоретико-прикладные аспекты применения инструментов туристической индустрии для развития постконфликтных территорий. $M e$ тоды, использованные в исследовании: системный подход, структурно-логический и статистический анализ, синтез, обобщение. Гипотеза исследования: предусматривает использование подхода, согласно которому развитие территории средствами туризма рассматривается как альтернативная стратегия восстановления социально-экономического благосостояния для жителей региона. Изложение основного материала: обзор предыдущих исследований и современных историческизафиксированных фактов решения проблем постконфликтных территорий позволил выделить четыре негативных и четыре положительных предпосылки, наличие которых обосновывает целесообразность использования инструментов туристической отрасли для развития таких проблемных регионов. Оригинальность и практическая значимость исследования: результаты исследования, проведенного по данным Луганской и Донецкой области, доказывают, что туризм не станет ведущей отраслью экономики именно для этих регионов, но его внутренне-региональное развитие будет катализатором для восстановления других отраслей экономики. Выводы и перспективы дальнейших исследований: учитывая имеющийся скептицизм относительно возможностей развития туризма на территории Донбасса, следующие исследования будут посвящены обоснованию целесообразности развития отдельных видов туризма именно в этом регионе нашей страны.

Ключевые слова:

постконфликтная территория, региональный туризм, инструменты, развитие, предпосылки, экономические и социальные проблемы.

Постановка проблеми. Регіони, що пережили на власній території відкритий конфлікт $з$ руйнуванням економічної системи, соціально-економічної інфраструктури та налагоджених економічних зв'язків постають перед проблемою відновлення всіх напрямів суспільної роботи, пов'язаних 3 життедіяльністю населення, рівнем та якістю його життя. Як засвідчує міжнародна практика, економічні і соціальні чинники не розглядаються у якості кореневих проблем виникнення міжрегіональних (міжнаціональних) конфліктів. Найчастіше, «каменем спотикання» $€$ політичні позиції учасників конфронтації, які генерують у подальшому соціально- економічні проблеми для самого конфліктного регіону, а також і для прилеглих до нього територій.

Натомість, вихід із кризи політичних взаємовідносин та подолання протилежних поглядів супроводжується налагодженням сталого діалогу, який має вирішити проблеми не тільки політичного, але, у першу чергу, економічного та соціального характеру. Відповідно, пропоновані механізми мають передбачати реалізацію системних зрушень, що виникатимуть за принципом відомого «ефекту доміно». Таку позитивну ланцюгову реакцію можуть забезпечити тільки економічні інструменти, але виникає питання: 3 
яких саме необхідно розпочинати, яка сфера економічної діяльності дозволить запустити зазначений механізм?

Останне десятиліття на світовій економічній арені відбувається заміна галузейлідерів економічного розвитку. Якщо раніше провідними були виробничі сфери діяльності, то $з$ часом на перші позиції щодо темпів росту виходять IT-індустрія, сфера послуг та, зокрема, туризм, частка якого у світовому ВВП складає вже більше 10\%. В Україні спостерігаються ті самі тенденції [1], але питома вага останньої галузі у національному ВВП набагато нижча і складає лише 1,5\% [2]. Враховуючи значущість окресленої проблеми для України у контексті реінтеграції депресивних постконфліктних територій на сході країни, актуальним $є$ питання доцільності розвитку туристичної галузі та її спроможності сприяти відновленню регіональних економічних систем.

Аналіз останніх досліджень та публікацій. Проблематика реінтеграції територій достатньо активно обговорюється у наукових колах. Загальних питань розвитку постконфліктних регіонів торкалися В. В. Михальська [3], Г. М. Заваріка [4], Н. О. Степанів та В. В. Сфременко [5]. Серед авторів, які розглядали проблему постконфліктного регіонального розвитку на тлі використання інструментів туристичної галузі, можна знову відзначити Г. М. Заваріку [6], а також О. О. Любіцеву [7], Л. М. Ткачук [8], тощо.

Критичний аналіз публікацій зазначених авторів дозволяє виділити наступні тези:

1) поняття «постконфліктна територія» не $є$ однозначним: деякі експерти ототожнюють його 3 «територією, що перебуває у перехідному стані»; інші стверджують, що це різні поняття визначаючи «постконфліктну територію», як таку де спостерігається стала позитивна динаміка руху від вже закритого конфлікту до встановлення мирних взаємовідносин всередині та ззовні, а у якості «території із перехідним станом» розглядають регіон, де існує загроза повернення до відкритого протистояння [4, с. 109]; другий підхід здається більш об'єктивним, адже наявність нестабільної ситуації суперечить сталому соціально-економічному розвитку;

2) постконфліктний розвиток території має передбачати: гарантування повної безпеки життєдіяльності, а також продовольчої безпеки (через повернення аграрного сектору) для населення регіону; відновлення регіо- нальної інфраструктури та, зокрема, роботи закладів соціального захисту, охорони здоров'я і освіти; відновлення легітимного громадського суспільства та структур місцевого самоврядування [5, с. 101-102];

3) для досягнення сталого розвитку постраждалого від конфлікту регіону необхідно впроваджувати спеціальну комплексну економічну політику із чітким координуванням донорських програм та врахуванням психологічного стану осіб, що залишилися та проживають на його території [3, с. 58-59];

4) за наявності як прихильників, так і супротивників, міжнародна практика вже містить результативний досвід розвитку постконфліктних територій із використанням інструментів туристичної галузі. Враховуючи перспективність цих заходів і зважаючи на наявні ризики, викликані загальною нестабільною політичною ситуацією, Всесвітня туристична організація наголошує своїм членам про необхідність розробки національної політики щодо безпеки реалізації туристичної діяльності, а також формування спеціалізованих органів на національному та регіональному рівні, що відповідатимуть за управління ризиками в межах кожного регіону як туристичної дестинації [8, с. 35].

Визначення невирішеної частини проблеми. Незважаючи на накопичений позитивний досвід та підтверджені факти ефективності розвитку території засобами туризму, існує багато скепсису щодо перспективності їх використання саме для розвитку постконфліктних регіонів. Жоден 3 представлених вище та інших авторів не наводить розгорнутого обгрунтування доцільності впровадження інструментів туристичної галузі для реінтеграції постраждалих від конфлікту територій у національне та світове співтовариство.

Мета статті. Враховуючи все вищезазначене, метою даного дослідження є систематизація та аналіз наявного досвіду, визначення економічних та соціальних передумов розвитку постконфліктних територій інструментами туристичної галузі на прикладі сходу України.

Виклад основного матеріалу дослідження. Історія розвитку конфлікту у східній частині України ще не закінчена. У попередніх публікаціях п’ятирічної давнини вже здійснювався аналіз можливих напрямів розвитку туризму зокрема у Луганській області [9]. Але, наша країна і досі має тери- 
торії, які за визначенням підпадають під поняття «постконфліктних». Ними залишаються частина Луганської і Донецької областей, які буди деокуповані протягом проведення АТО починаючи 3 середини 2014 р. Незважаючи на те, що території формально перебувають під контролем України, повної реінтеграції у національне соціально-економічне середовище країни так і не відбулося. За більшістю показників обидві області займають у національних рейтингах останні позиції. По деяким комплексним індексам регіонального розвитку для даних регіонів розрахунки взагалі не здійснюються. Зокрема, серед таких можна виділити інтегральний індекс регіонального людського розвитку, розрахунок якого передбачає використання показників, що характеризують відтворення населення, соціальне середовище, комфортність умов життя та добробут, якість освіти та умови праці. Виключення Луганської та Донецької області із загального рейтингу регіонів України свідчить про відсутність можливості здійснення адекватного оцінювання поточної ситуації щодо стану та динаміки показників людського розвитку на Донбасі протягом останніх п’яти років.

Для визначення доцільності розвитку туристичної галузі у обох регіонах необхідно ідентифікувати основні економічних проблеми, що спостерігаються на території обох областей. Серед них:

-низький рівень зайнятості: 3 початку конфлікту рівень зайнятості у Луганській області не перевищував 58\% [10], у Донецькій області він був не вище 51\% [11];

-найнижчий по Україні наявний дохід на 1 особу: у Луганській області станом на 2018 р цей показник складав - 20618,6 грн. [10]; у Донецькій - 31888,0 грн. на рік [11];

-втрата економічних зв'язків та ринків збуту: значна кількість підприємств обох областей залишилася без постачальників та опинилася перед проблемою пошуку нових ринків збуту власної продукції;

-неналежний стан регіональної транспортної інфраструктури;

-несприятливий імідж регіонів, як територій некомфортних для ведення бізнесу.

Серед основних соціальних проблем, 3 якими стикнулися Луганщина і Донеччина, можна виділити наступні:

-незадовільний стан соціальної інфраструктури;

-низький рівень якості соціальних послуг; -відсутність можливостей самореалізації особистості;

-споживацька позиція більшої частини населення, відсутність відповідальності за власне майбутнє;

Як наслідок, високий рівень трудової міграції працездатного населення за межі Луганської та Донецької областей: у 2018 р. кількість осіб, що покинули регіон склала 5,6 тис. осіб та 10,3 тис. осіб відповідно. Це найгірші показники серед всіх областей країни.

Український Донбас ніколи не розглядався як дуже приваблива туристична дестинація, він не витримував конкуренцію 3 західними та південними областями країни. Але перед подіями 2014 року всередині регіону розвивався промисловий, сільський зелений, лікувально-оздоровчий, спортивний, культурно-пізнавальний туризм.

Враховуючи той факт, що більшість бюджетоутворюючих у минулому промислових підприємств-гігантів залишились на окупованій території, їх економічні взаємовідносини 3 Україною повністю припиненою, а значна кількість тих, що розташовані на підконтрольній частині областей, перебувають у незадовільному матеріальнотехнічному стані із застарілими технологіями виробництва, виникає питання: яким чином можливо вирішити визначені вище економічні та соціальні проблеми?

Експерти 3 політичної психології відзначають, що довіра та бажання співпрацювати не відновлюються миттєво. Має пройти певний проміжок часу, але міжнародна практика підтверджує, що є заходи, які прияють відновленню взаємовідносин. Таким інструментом стають спільні економічні заходи: виставки, форуми, конгреси, ярмарки, до участі в яких запрошуються i представники постконфліктних територій. Вони у свою чергу в майбутньому можуть виступати ініціаторами та організаторами таких подій у власних регіонах. Таку практику успішно використовували свого часу в Косово та у Хорватії, цілеспрямовано організовуючи економічні заходи саме на проблемних територіях з метою поновлення та формування нових партнерських взаємовідносин [3, с. 56]. Представлені факти є підтвердженням доцільності використання інструментів туристичної галузі (у даному випадку ділового, конгрес-туризму) для каталізації розвитку депресивних постконфліктних регіонів. 
Органи влади Луганської і Донецької областей вже зробили перші кроки, продемонструвавши діяльність, спрямовану на відновлення туристичної галузі. Визначивши туристичну сферу діяльності, як одну 3 найбільш перспективних на обласному та місцевому рівні було розроблено ряд основоположних документів. Зокрема, на Донеччині у 2019 р. підбили підсумки реалізації «Програми розвитку туризму в Донецькій області на 2016 - 2018 роки» [12], на Луганщині у червні 2019 р. була затверджена «Концепція розвитку туризму в Луганській області до 2022 року» [13]. У 2019 р. області вперше за останні роки взяли участь у міжнародних туристичних виставках (зокрема у міжнародному туристичному салоні «Україна» UITM'2019), представивши наявний потенціал для розвитку принаймні внутрішньорегіонального туризму. У той же час на власній території було організовано та успішно проведено цілий ряд заходів із залученням

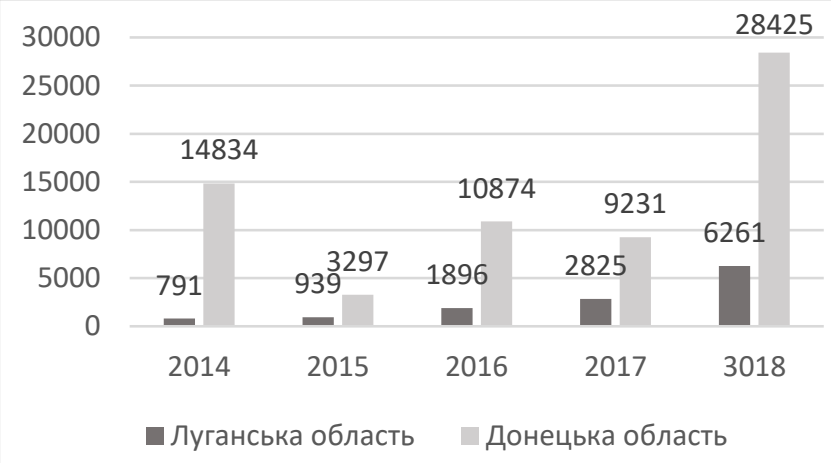

Рисунок 1 - Кількість туристів, обслугованих туроператорами та турагентами (осіб) Джерело: [10, 11]

Аналізуючи представлену статистику, неможна не зауважити, що левова частка мандрівників - це ті, хто виїжджає за межі країни. На Луганщині питома вага внутрішніх туристів у 2018 р. склала тільки $1,3 \%$, на Донеччині - 19,6\%; для порівняння у 2013 р. ці показники відповідно дорівнювали - 37,3 та $28,3 \%$. Про іноземних відвідувачів взагалі поки що не ідеться. Така негативна динаміка внутрішнього туризму на тлі відновлення загального туристичного потоку свідчить про те, що більшість місцевого населення не має уявлення про можливості відпочинку в межах регіону. Відтак значна сума коштів, яку витрачають на відпочинок туристи, не залишається в регіоні, а взагалі «витікає» на закордонні рахунки іноземних туристичних компаній. 3 іншого боку, судячи з офіційних джерел, стати- зовнішніх учасників: «Open Data Forum», форум регіонального партнерства «Стратегія в діï», «RE: THINK Invest in Ukraine», тощо.

Визнання туристичної галузі, як перспективної для Донбасу сфери економічної діяльності активно критикується у відкритих 3MI, особливо скептично відносяться зовнішні експерти до можливостей Луганщини [14], наголошуючи на тому, що ані наявні ресурси, ані визначена концепція розвитку не дозволять відновити туристичну галузь хоча б до рівня 2013 р. Натомість, регіональна статистика за останні п'ять років засвідчує, що кількість населення, яке скористалося послугами туроператорів та турагентів в Луганській і Донецькій області поступово зростає (рис. 1). Відновлення роботи суб'єктів туристичної діяльності також є індикатором позитивних змін, їх кількість, якщо порівнювати 3 іншими регіонами, мізерна, але тільки за 2018 рік вона зросла майже вдвічі (рис. 2).

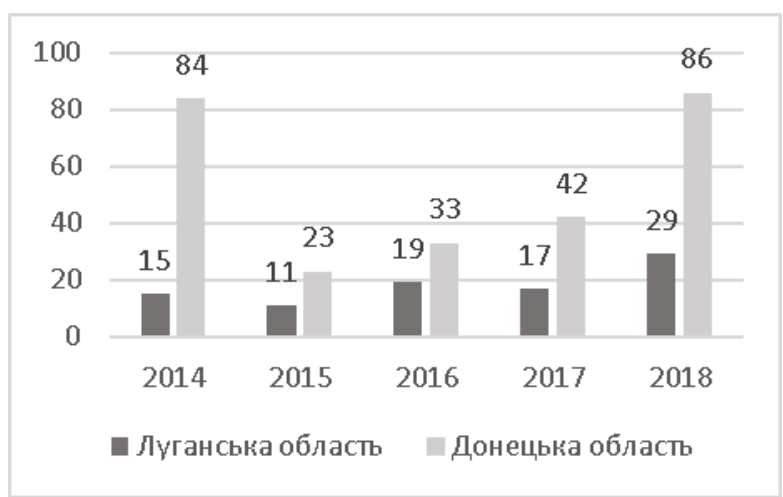

Рисунок 2 - Кількість суб'єктів туристичної діяльності (одиниць) Джерело: [10, 11]

стика не відображає реальної ситуації. Так, за словами Л. Ахтирської (заступника директора Депертаменту економіки, торгівлі та туризму Луганської обласної державної адміністрації), про іноземних відвідувачів на Луганщині дійсно говорити зарано (iх кількість і раніше, починаючи 32000 р. і до 2014 р., не перевищувала 700 осіб на рік), але за адміністративними даними у 2016 р. область відвідало близько 3 тис. осіб з інших регіонів України [15]. Цей показник разюче відрізняється від офіційної цифри, за той самий період.

Аналізуючи туристичний потенціал регіонів, можна відзначити, що у дещо кращому становищі перебуває Донецька область, в якій більша частина відомих туристичних принад залишилась на підконтрольній території. У Луганській області зворотна ситуація - біль- 
шість відомих туристичних об'єктів поки що недоступна, тому регіональні органи влади вимушені розпочинати розвиток туристичної галузі майже «з нуля». 3 іншого боку Луганщина випереджає свого сусіда у роботі над ребрендингом, створивши у 2018 р. новий бренд області «Луганщина моя». Донецька область, у свою чергу, у 2019 презентувала новий туристичний бренд Лиманської об'єднаної територіальної громади.

Висновки та перспективи подальших досліджень. Підсумовуючи результати дослідження, можна визначити, що використання засобів туризму для розвитку постконфліктних територій доцільне при наявності наступних передумов:

1) зруйнованість соціально-економічних взаємовідносин, які можливо відновити засобами ділового туризму;

2) проблема низької зайнятості на фоні відсутності широких можливостей працевлаштування на промислових підприємствах. Вже доведено, що створення одного робочого місця в туристичній сфері генерує одразу декілька нових у суміжних галузях (легка, харчова промисловість, будівництво тощо);

3) обмежені можливості для творчої самореалізації місцевого населення. Розвиток туристичної галузі відбувається на тлі активізації креативних сфер діяльності та ремісного мистецтва, організації відповідних культурноісторичних заходів, мистецьких фестивалів, ярмарок хенд-мейд виробів тощо;

4) негативний імідж регіонів як територій з несприятливим інвестиційним кліматом та небезпечних для пересування мандрівників. Відновлення внутрішньо-регіонального туризму продемонструє зовнішнім відвідувачам безпечність пересування, а підвищення економічної привабливості територій можливо здійснити за рахунок створення пільгових умов для ведення малого та середнього бізнесу, зокрема $\mathrm{i}$ для суб'єктів туристичної діяльності.

Вирішення представлених економічних $\mathrm{i}$ соціальних проблем засобами туризму можливе за умови наявності сприятливих факторів розвитку, які також можна віднести до позитивних передумов, серед них:

-стале партнерство між регіональними органами влади разом із представниками бізнесу та місцевими громадами, готовими розвивати туристичну сферу власної місцевості;

-наявність реальних, або потенційнопривабливих туристичних ресурсів, здатних залучити нових відвідувачів регіону;

-доступність реальних джерел фінансування (кошти державного, регіонального та місцевих бюджетів, міжнародних організацій, грантових програм, юридичних та фізичних осіб-підприємців);

-нормативно-законодавча підтримка регіонального розвитку туристичної галузі на державному рівні;

I Луганщина і Донеччина серед представленого переліку позитивних факторів гостро відчувають брак першого з них: більша частина місцевого населення не усвідомлює перспективність розвитку туристичної галузі, а тому головною умовою успішності має стати потужна інформаційно-просвітницька кампанія, що дозволить членам громад сформувати уявлення про власний регіон, як про територію привабливу для подорожування i для них самих, а у подальшому і для відвідувачів з інших областей країни.

\section{Література}

1. Проблемні та перспективні: які галузі зараз формують ВВП України. Україна молода. 2019. 13 березня. URL: https://www.umoloda.kiev.ua/number/3433/159/13 1298/\# (дата звернення: 10.11.2019 p.)

2. Доля туризма в ВВП Украины в 10 раз ниже средней по миру. UAnews. 2019. 12 лютого. URL: https://ua.news/ru/chastka-turyzmu-uvvp-ukrayiny-u-10-raziv-nyzhche-serednoyi-posvitu/ (дата звернення: 13.11.2019 p.)

3. Михальська В. В. Постконфліктні управлінські практики в економічній політиці. Політичне життя. 2018. № 2. C. 55-60.

4. Заваріка Г. М. Розвиток країн у постконфліктних ситуаціях. Галицький економічний вісник. 2015. № 2. С. 107-114.

5. Степанів Н. О., Єфременко В. В. Напрями соціально-економічного розвитку постконфліктних території. Збірник наукових праць Донбаської начіональної академї будівниитва і архітектури. 2018. № 1. С. 99-105.

6. Заваріка Г. М. Економіко-географічні чинники розвитку туризму сходу України в період конфлікту. Вісник Львівського універсиmету. Серія географічна. 2018. - Випуск 52. С. 100-109.

7. Любіцева О. О., Заваріка Г. М. Стратегічні напрямки розвитку туризму Луганської області в постконфліктний період. Науковий вісник Херсонського державного університету. Серія: Географічні науки. 2019. Вип. 11. С. 51-60.

8. Ткачук Л. М. Вплив політичної нестабільності на розвиток туристичної дестинації. Географія та туризм. 2016. Вип. 37. C. 26-36. 
9. Зеленко О. О. Перспективи розвитку туризму Луганщини в умовах воєннополітичної нестабільності. Науковий вісник Мyкачевського державного університету. Серія: Економіка. 2015. № 2. С. 138-143.

10.Офіційний вебсайт Головного управління статистики у Луганській області: URL: http://lg.ukrstat.gov.ua (дата звернення: 14.11.2019 p.)

11.Офіційний вебсайт Головного управління статистики у Донецькій області: URL: http://donetskstat.gov.ua (дата звернення: 14.11.2019 p.)

12.Програми розвитку туризму в Донецькій області на 2016 - 2018 роки. Ligazakon. URL: https://ips.ligazakon.net/document/DO16019 (дата звернення: 14.11.2019 р.)

13.Концепиія розвитку туризму в Луганській області до 2022 року. Ligazakon. URL: http://search.ligazakon.ua/1_doc2.nsf/link (дата звернення: 14.11.2019 р.)

14.Іванова В. Туризм на Луганщині: Як відродити те чого ніколи не було . Depo.UA. 2019. 6 червня. URL: https://dn.depo. ua/ukr/severodonetsk/turizm-na-luganshchini-yakvinayti-te-chogo-nikoli-ne-bulo-20190605974 (дата звернення: 14.11.2019 р.)

15.Луганщина туристична. Як область реалізує стратегію прориву. ВістіЛуг. 2018. 9 жовтня. URL: http://vistilug.com.ua/ news/3364luganshchina-turistichna-yak-oblast-ryealizovuestrategiyu-prorvu/ (дата звернення: 14.11.2019 р.)

\section{Reference}

1. Problematic and promising: what sectors are currently shaping Ukraine's GDP (2019). Ukraine Young. March 13. Retrieved from: https://www.umoloda.kiev.ua/number/34/131298/\#

2. The share of tourism in the GDP of Ukraine is 10 times lower than the world average (2019). UAnews. February 12. Retrieved from: https://ua.news/en/chastka-turyzmu

3. Mikhalska, V. V. (2018) Postconflicted management practices in economic politicsю. Political Life, 2, 55-60.
4. Zavarika, H. M. (2015) Development of countries in post-conflict situations. Galician Economic Bulletin, 2, 107-114.

5. Stepaniv, N. O. \& Efremwnko, V. V. (2018) Directions of socio-economic development for post-conflict territories. Proceedings of the Donbas National Academy of Civil Engineering and Architecture, 1, 99-105.

6. Zavarika, H. M. (2018). Economic and geographical factors of tourism development of eastern Ukraine during the conflict. Visnyk of Lviv National University. The geographical series, 52. 100-109.

7. Lyubitseva, O. O. \& Zavarika, H. M. (2019). Strategic directions of tourism development in the Lugansk region in the post-conflict period. Scientific Bulletin of the Kherson State University. Series: Geographical Sciences. 11. 51-60.

8. Tkachuk, L. M. (2016) Influence of political instability on the development of tourist destination. Geography and Touris, 37, 26-36.

9. Zelenko, O. O. (2015) Prospects for the development of tourism in the Luhansk region in conditions of military-political instability. Scientific Bulletin of the Mukachevo State University. Series: Economics, 2, 138-143.

10. Main Department of Statistics in Luhansk Oblast: official website. Retrieved from: http://lg.ukrstat.gov.ua

11. Main Department of Statistics in Donetsk Oblast: official website. Retrieved from: http://donetskstat.gov.ua

12. Tourism Development Programs in Donetsk Region for 2016-2018 (2016). Ligazakon. Retrieved from: https://ips.ligazakon.net/document

13. The concept of tourism development in the Luhansk region until 2022 (2019). Ligazakon. Retrieved from: http://search.ligazakon.ua

14. Ivanova, $V$. (2019). Tourism in the Luhansk region: How to revive what never happened. Depo.UA. June 6. Retrieved from: https://dn.depo.ua/eng/severodonetsk/turizm- naluganshchini-yak-vinayti-te-chogo190605974252

15. Tourist Luhansk region. How an area implements a breakthrough strategy. (2018). VistiLug. October 9. Retrieved from: http://vistilug.com.ua/news/3364-luganshchinaturistichna-yak-oblast-ryealizovue

\footnotetext{
Стаття прийнята

до друку: 27.12.2019 р.
}

Стаття надійшла

до редакції : 15.11.2019 p.
Бібліографічний опис для цитування :

Зеленко О. О. Економічно-соціальні передумови розвитку постконфліктної території засобами туризму / О. О. Зеленко // Часопис економічних реформ. - 2019. - № 4 (36). - С. 6-12. 